\title{
Correction to: Communicating future climate projections of precipitation change
}

\author{
Joseph Daron ${ }^{1,2}$ (D) Susanne Lorenz ${ }^{3} \cdot$ Andrea Taylor $^{3,4} \cdot$ Suraje Dessai ${ }^{3}$
}

Published online: 20 July 2021

(C) The Author(s) 2021

\section{Correction to: Climatic Change https://doi.org/10.1007/s10584-021-03118-9}

The original article has been corrected. The affiliation Leeds University Business School, Leeds, UK for author Andrea Taylor was missing from the original publication. This has been added.

Open Access This article is licensed under a Creative Commons Attribution 4.0 International License, which permits use, sharing, adaptation, distribution and reproduction in any medium or format, as long as you give appropriate credit to the original author(s) and the source, provide a link to the Creative Commons licence, and indicate if changes were made. The images or other third party material in this article are included in the article's Creative Commons licence, unless indicated otherwise in a credit line to the material. If material is not included in the article's Creative Commons licence and your intended use is not permitted by statutory regulation or exceeds the permitted use, you will need to obtain permission directly from the copyright holder. To view a copy of this licence, visit http://creativecommons.org/licenses/by/4.0/.

Publisher's note Springer Nature remains neutral with regard to jurisdictional claims in published maps and institutional affiliations.

The online version of the original article can be found at https://doi.org/10.1007/s10584-021-03118-9

Joseph Daron

joseph.daron@metoffice.gov.uk

1 Met Office, Exeter, UK

2 Faculty of Science, University of Bristol, Bristol, UK

3 School of Earth and Environment, University of Leeds, Leeds, UK

4 Leeds University Business School, Leeds, UK 